$\underline{\text { Research Article }}$

\title{
In vitro study to determine antimicrobial activity of selected Ayurvedic preparations against bacteria and fungi causing superficial skin infections
}

\author{
PLR Gomes ${ }^{1}$, S Hewageegana ${ }^{2}$, J Kottahachchi ${ }^{1}$, GIDDAD Athukorala ${ }^{1}$, \\ MM Weerasekera ${ }^{1}$, TDCP Gunasekera ${ }^{1}$, DMBT Dissanayake ${ }^{1}$, DFD Meedin ${ }^{1}$, \\ SSN Fernando ${ }^{1}$
}

Sri Lankan Journal of Infectious Diseases 2013 Vol.3(1);32-39

DOI: http://dx.doi.org/10.4038/sljid.v3i1.4717

Key words: Superficial skin infections, Ayurvedic preparations

\begin{abstract}
The increasing antimicrobial resistance exhibited by microorganisms causing superficial skin infections has led to extensive research on the therapeutic potential of Ayurvedic preparations. Medicinal plants contain many types of naturally occurring and side effectsfree anti microbial compounds that can be effectively used against microbial infections. We tested the antimicrobial activity of twenty-eight Ayurvedic preparations used to treat superficial infections in a local Ayurvedic healthcare institution. They were tested against Trichophyton rubrum, Microsporum gypseum, Candida albicans, Malassezia furfur, Staphylococcus aureus and Streptococcus pyogenes. Twelve preparations showed significant antimicrobial activity and gave inhibition zones $>10 \mathrm{~mm}$. Two Ayurvedic preparations (Mixture containing Terminella chebula, Terminella bellerica and Emblica officinalis and one of Terminella chebula only ) showed antimicrobial activity against all the microorganisms tested. We suggest that these two decoctions could be effectively used against all the above tested strains.
\end{abstract}

\section{Introduction}

Superficial skin infections are very common in general practice and are caused by bacteria, fungi and viruses. Bacteria such as Staphylococcus aureus and Streptococcus pyogenes are responsible for the majority of superficial infections. ${ }^{1}$ Fungal infections of the skin, nails and hair are commonly caused by dermatophytes, Candida albicans and Malassezia furfur. ${ }^{2}$

${ }^{1}$ Department of Microbiology, Faculty of Medical Sciences, University of Sri Jayewardenepura

${ }^{2}$. Department of Kaya Chikitsa, Institute of Indigenous Medicine, University of Colombo.

Address for correspondence: Gomes PLR, Department of Microbiology Faculty of Medical Sciences, University of Sri Jayewardenepura. E mail.laksiri79@yahoo.com 
Treatment of superficial skin infections is mainly based on the use of topical antibacterial and antifungal agents. However, the indiscriminate use of antimicrobial agents has led to antimicrobial resistance. Development of antimicrobial resistance has been found in both bacteria and fungi that cause superficial skin infections. ${ }^{3-6}$

The increasing antimicrobial resistance exhibited by microorganisms causing superficial skin infections has led to extensive research on the therapeutic potential of Ayurvedic preparations. Medicinal plants contain many types of naturally occurring anti microbial compounds that can be effectively used against microbial infections. ${ }^{7}$ Alkaloids, flavones (flavonoids, flavonols, Quinones), essential oils, lectins, polypeptides, phenolics, polyphenols, tannins and terpenoids are the major groups of naturally occurring antimicrobial agents that can be extracted from medicinal plants. ${ }^{8}$

Currently there are about 29 Ayurvedic preparations used to treat superficial skin infections. In vitro testing has been sparsely carried out to evaluate the effectiveness of these preparations against standard strains. A comprehensive in vitro study will provide valuable scientific information towards the development of more effective topical Ayurvedic applications for superficial infections. Therefore, in order to determine the antimicrobial activity, we investigated 28 Ayurvedic preparations against six common microorganisms causing superficial skin infections including Trichophyton rubrum, Microsporum gypsum, Candida albicans, Malassezia furfur, Staphylococcus aureus and Streptococcus pyogenes.

\section{Methodology}

\section{Ayurvedic preparations}

Twenty-eight Ayurvedic preparations used to treat superficial skin infections were kindly provided by a local Ayurvedic healthcare institution. The medicinal plants used for the preparations are listed in table 1.

\section{Antimicrobial activity against bacteria}

The antibacterial activity of each Ayurvedic preparation was tested against Staphylococcus aureus ATCC 25923 and Streptococcus pyogenes using the agar well method. ${ }^{9,10}$ The diameter of a well was $7 \mathrm{~mm}$ and had a height of $4 \mathrm{~mm}$. For each strain, a suspension was prepared in sterile normal saline and turbidity adjusted to $0.5 \mathrm{McF}$ arland standard. The suspension of organisms was used to inoculate blood agar plates to obtain a confluent growth. Wells were cut in the agar surface with the help of a cork borer. Each well was filled with $100 \mu 1$ of the Ayurvedic preparation. At the same time, cefoxitin 30 $\mu \mathrm{g}$ and penicillin $10 \mu \mathrm{g}$ discs were tested against Staphylococcus aureus and Streptococcus pyogenes respectively. All the plates were incubated 24 hours at $37^{\circ} \mathrm{C}$ before measuring the inhibition zone sizes. Any zone of inhibition around the decoction containing wells was considered as sensitive. 
Table 1: Medicinal plants used for the Ayurvedic preparations included in the study

\begin{tabular}{|c|c|c|c|c|}
\hline No & $\begin{array}{l}\text { Herbs used for the Ayurvedic } \\
\text { preparation }\end{array}$ & $\begin{array}{l}\text { Part of the plant } \\
\text { used }\end{array}$ & $\begin{array}{c}\text { Sinhala name of the } \\
\text { herb }\end{array}$ & English name of the herb \\
\hline 1 & Ficus religiosa Linn. & Bark & $\mathrm{Ba}$ & Sacred fig \\
\hline 2 & Thespesia papu/nea (L.) Sol. & Leaves/Bark & Gansuriya & Portia tree \\
\hline 3 & Ficus racemosa Linn. & Bark & Attikka & Cluster fig \\
\hline 4 & Coscinium fenestratum (Gaertn) Colb & Stem & Wenival-geta & Columbo weed \\
\hline 5 & $\begin{array}{l}\text { Azadirachta indica A. Juss. Lurcuma } \\
\text { longaLinn. }\end{array}$ & $\begin{array}{l}\text { Leaves } \\
\text { Rhizome }\end{array}$ & $\begin{array}{l}\text { Kohomba } \\
\text { Amu kaha }\end{array}$ & $\begin{array}{l}\text { Margasa } \\
\text { Turmeric }\end{array}$ \\
\hline 6 & Azadirachta indica A. Juss. & Bark & Kohomba & Margasa \\
\hline 7 & Glycyгrhiza glabra Linn. & Stem & Valmee & Licarice \\
\hline 8 & Emblica afficinalis Linn. & Fruit & Nelli & Indian gooseberгy \\
\hline 9 & Hemidesmus indicus L.R.Br & Root & Iramusu & Indian sarsaparilla \\
\hline 10 & Rubia cardifaliaLinn. & Root & Welmadata & Indian madder \\
\hline$\|$ & $\begin{array}{l}\text { Termine/la chebula Retz. } \\
\text { Terrmine/la belerica Roxb. Emblica } \\
\text { afficinalis Linn. }\end{array}$ & $\begin{array}{l}\text { Fruit } \\
\text { Fruit } \\
\text { Fruit }\end{array}$ & $\begin{array}{l}\text { Aralu } \\
\text { Bulu } \\
\text { Nelli }\end{array}$ & $\begin{array}{c}\text { Black myrobalan } \\
\text { Beleric myrobalan } \\
\text { Indian gooseberry }\end{array}$ \\
\hline 12 & Garcinia cambagia Pierre. & Fruit & Goraka & Malabar tamarind \\
\hline 13 & Mimosa pudica Linn. & Rout & Nidikumba & Sensitive plant \\
\hline 14 & Terminella chebula Retz. & Fruit & Aralu & Black myrobalan \\
\hline 15 & $\begin{array}{l}\text { Curcuma langa Linn. } \\
\text { Mimosa pudica Linn. }\end{array}$ & $\begin{array}{l}\text { Rhizome } \\
\text { Root }\end{array}$ & $\begin{array}{c}\text { Kaha } \\
\text { Nidikumba }\end{array}$ & $\begin{array}{c}\text { Turmeric } \\
\text { Sensitive plant }\end{array}$ \\
\hline 16 & Baсора munnieri(L.) Pennell & Whole plant & Lunuwila & Water hyssop \\
\hline 17 & Achyranthes aspera Linn. & Whole plant & Karal sebo & Prickly Chaff-flower \\
\hline 18 & Acasia chundra (Raxb)DC. & Stem & Rat khiriya & Red cutch \\
\hline 19 & Cassia fistula Linn. & Bark & Ahala & Golden shower tree \\
\hline 20 & Holarrhena antidysenterica (Linn.) wall. & Bark & Kelinda & Bitter oleander \\
\hline 21 & Bauhinia acuminata Linn. & Bark & Koboleela & Dwarf White Bauhinia \\
\hline 22 & Cyperus rotundus Linn. & Rhizome & Kalanduru & Nut grass \\
\hline 23 & Syzygium cumini(Linn.) Skeels. & Bark & Ma-dam & India Jamun \\
\hline 24 & Curcuma zedoaria (Christm.) Roscae. & Rhizome & Harankaha & White turmeric \\
\hline 25 & Symplocos racemosaRaxb. & Bark & Lothsumbul & Lodh tree \\
\hline 26 & Nardostachys jatamansiDC. & Rout & Jatamangsha & Muskraot \\
\hline 27 & Mangifera indica Linn. & Bark & Amba & Manga \\
\hline 28 & Carissa cangesta Wight. & Bark & Karanda & Christ's Tharn \\
\hline
\end{tabular}

\section{Antimicrobial activity against dermatophytes and Candida}

Using the same method, the Ayurvedic preparations and ketoconazole 10 $\mu \mathrm{g}$ disc were tested against standard strains of Trichophyton rubrum, Microsporum gypseum and Candida albicans on Sabouraud agar. ${ }^{11,12}$ For dermatophytes, the plates were incubated at $30^{\circ} \mathrm{C}$ for 7 days. Zones for Candida albicans were interpreted after incubating the plates for 24 hours at $37^{\circ} \mathrm{C}$. 


\section{Antimicrobial activity against Malassezia furfur}

Similarly the activity of the Ayurvedic preparations and ketoconazole $10 \mu \mathrm{g}$ disc against a standard strain of Malassezia furfur was tested on Sabouraud agar supplemented with 3\% tween 20 . The results were interpreted after an incubation period of 48 hours at $37^{\circ} \mathrm{C}$.

\section{The effect of freezing on the antimicrobial activity}

An aliquot of each Ayurvedic preparation was frozen for 7 days at $-80^{\circ} \mathrm{C}$ and tested simultaneously for all the microorganisms along with the normal solution. The inhibition zones were compared in order to determine any effect of freezing on the antimicrobial activity of the preparations.

\section{The potency of the Ayurvedic preparations}

For each strain, a suspension was prepared in sterile normal saline and the turbidity was adjusted to $0.5 \mathrm{McFarland}$ standard. The suspension $(100 \mu \mathrm{l})$ was mixed separately with $900 \mu \mathrm{l}$ of each decoction that showed antimicrobial activity. The mixture was incubated at $37^{\circ} \mathrm{C}\left(30^{\circ} \mathrm{C}\right.$ for dermatophytes) and plated on appropriate media at 30 minutes and 60 minutes intervals. The plates were incubated overnight at $37^{\circ} \mathrm{C}\left(30^{\circ} \mathrm{C}\right.$ for dermatophytes $)$ and observed for complete inhibition of the microorganism. A mixture with $100 \mu \mathrm{l}$ of suspension and $900 \mu \mathrm{l}$ of sterile normal saline was used as the control. Five ten-fold dilutions were prepared from each decoction that inhibited growth after overnight incubation at $37^{\circ} \mathrm{C}\left(30^{\circ} \mathrm{C}\right.$ for dermatophytes $)$ and observed for complete inhibition of the microorganism. The above experiment was performed for each dilution.

All experiments were performed in triplicates to ensure reproducibility of results.

\section{Results}

Out of the 28 Ayurvedic preparations, 12 showed antimicrobial activity against at least one microorganism tested. The antimicrobial activity of these 12 preparations is summarized in Table 2. All preparations that showed antimicrobial activity gave inhibition zones $>10 \mathrm{~mm}$. Two Ayurvedic preparations [the mixture of $T$ chebula, $T$ belerica and E officinalis and T chebula ] showed antimicrobial activity against all the microorganisms tested. Emblica officinalis also showed activity against all the test organisms except Candida albicans. Nardostachys jatamansi was only effective against Streptococcus pyogenes and Syzygium cumini showed activity against Staphylococcus aureus only. 
Table 2: Medicinal preparations that showed antimicrobial activity

\begin{tabular}{|c|c|c|c|c|c|c|c|}
\hline No & $\begin{array}{l}\text { Herbs used for the Ayurvedic } \\
\text { preparation }\end{array}$ & S.aur & S.pyo & C.alb & M.fur & T.rub & M.gyp \\
\hline 미 & Coscinium fenestratum(Gaertn) Colb & $18 \mathrm{~mm}$ & $22 \mathrm{~mm}^{\dagger}$ & $28 \mathrm{~mm}^{\dagger}$ & № ZOI & $30 \mathrm{~mm}$ & №ZUI \\
\hline Q2 & Azadirachta indica A. Juss. & $12 \mathrm{~mm}^{\dagger}$ & $15 \mathrm{~mm}^{\dagger}$ & No ZDI & № ZOI & $15 \mathrm{~mm}^{\dagger}$ & $15 \mathrm{~mm}^{\dagger}$ \\
\hline 03 & Glycyгrhiza glabra Linn. & NozZl & $12 \mathrm{~mm}^{*}$ & $\mathrm{NoZZI}$ & No ZZI & $35 \mathrm{~mm}$ & $32 \mathrm{~mm}^{\dagger}$ \\
\hline 04 & Emblica afficinalis Linn. & $14 \mathrm{~mm}^{\dagger}$ & $15 \mathrm{~mm}$ & No ZOI & $24 \mathrm{~mm}^{\dagger}$ & $30 \mathrm{~mm}$ & $41 \mathrm{~mm}^{*}$ \\
\hline$\overline{05}$ & Rubia cardifaliaLinn. & NoZZI & $16 \mathrm{~mm}$ & $\mathrm{~N}_{\mathrm{Z}}$ ZDI & № ZOI & $25 \mathrm{~mm}^{*}$ & $36 \mathrm{~mm}$ \\
\hline Q6 & $\begin{array}{l}\text { Terminella chebula Retz. } \\
\text { Terminella belerica Raxb. } \\
\text { Emblica afficinalis Linn. }\end{array}$ & $11 \mathrm{~mm}^{\dagger}$ & $30 \mathrm{~mm}$ & $15 \mathrm{~mm}^{\dagger}$ & $22 \mathrm{~mm} *$ & $42 \mathrm{~mm}^{*}$ & $35 \mathrm{~mm}$ \\
\hline 07 & Terminella chebula Retz. & $13 \mathrm{~mm}^{\dagger}$ & $25 \mathrm{~mm}$ & $22 \mathrm{~mm}^{\dagger}$ & $20 \mathrm{~mm}^{\dagger}$ & $40 \mathrm{~mm}^{\dagger}$ & $40 \mathrm{~mm}^{*}$ \\
\hline$\overline{08}$ & Cassia fistula Linn. & $15 \mathrm{~mm}^{\dagger}$ & $15 \mathrm{~mm}^{*}$ & No ZOI & No ZOI & $14 \mathrm{~mm}^{*}$ & $15 \mathrm{~mm}^{*}$ \\
\hline 99 & Syzygium cumini(Linn.) Skeels. & №ZZI & $\mathrm{N}_{\mathrm{Z} Z \mathrm{ZDI}}$ & $\mathrm{N}_{\mathrm{Z} Z \mathrm{ZI}}$ & No ZOI & $N_{0} Z$ ZI & $\mathrm{N}_{\mathrm{Z}} \mathrm{ZOI}$ \\
\hline 10 & Nardastachys jatamansiDC. & NoZZI & $16 \mathrm{~mm}^{\dagger}$ & $\mathrm{NoZZI}$ & $\mathrm{NaZZI}$ & NNoZU| & NNaZDI \\
\hline II & Mangifera indica Linn. & NoZOL & $12 \mathrm{~mm}^{\dagger}$ & NoZOI & NoZZI & $14 \mathrm{~mm}^{\dagger}$ & $12 \mathrm{~mm}^{\dagger}$ \\
\hline
\end{tabular}

ZOI -zone of inhibition, * - exposure for 30 min to the $\mathrm{IO}^{-5}$ dilution of preparation inhibited growth, ${ }^{\dagger}$ - activity was observed in well-methad anly

Apart from the two preparations that showed antimicrobial activity against all the microorganisms tested, decoctions made from A.indica, $G$ glabra, E. officinalis, $R$ cordifolia, $C$. fistula and $M$ indica were also effective against both dermatophytes tested. Only the decoction prepared from $T$ chebula, $T$ belerica, E officinalis mixture and $T$ chebula were active against $C$ albicans and $M$ furfur. $C$. fenestratum, A. indica, $E$. officinalis, and $C$. fistula are the medicinal plants used for other decoctions that were effective against both $S$ aureus and $S$ pyogenes. We did not notice any effect of freezing (for 7 days at $-80^{\circ} \mathrm{C}$ ) on the microbial activity of the medicinal plant preparations.

The results show (Table 2) that even the $10^{-5}$ dilution of most Ayurvedic preparations could inhibit the growth of tested microorganisms in exposure intervals as low as 30 minutes. For instance, an exposure of 30 minutes to $10^{-5}$ dilution of $T$ chebula, T belerica, E. officinalis mixture inhibited growth of all the tested microorganisms except $S$ aureus and $C$ albicans. When $T$ chebula alone was used such an exposure was effective only against $S$ pyogenes and $M$ gypsum. An overnight exposure to non-diluted preparation was necessary for a broad-spectrum activity.

\section{Discussion}

The results show that a high percentage of the tested herbal plants have potent antimicrobial activity. Even the $10^{-5}$ dilution of most Ayurvedic preparations showed efficient inhibitory action. To determine whether the preparations can be effectively used in superficial skin infections, a case control study on humans should be done. Most of the plants used in the preparations are widely distributed and used in ethnomedical 
preparations in Sri Lanka. We selected these 28 preparations since they are already used to treat superficial skin infections at the local Ayurvedic healthcare institution. S aureus and $S$ pyogenes were selected as the main bacterial strains since they are responsible for the majority of superficial infections. ${ }^{1}$ T rubrum, $M$ gypseum $C$ albicans and $M$ furfur are the commonest fungal species responsible for skin infections. ${ }^{2}$

Decoctions made from $T$. chebula, T. belerica, E. officinalis mixture and T. chebula showed the widest antimicrobial activity in our study. The broad-spectrum activity of $T$. chebula has been reported previously. ${ }^{13-16}$ Broad-spectrum antibacterial activity of $E$. officinalis and T. belerica has also been shown previously. ${ }^{17,}{ }^{18}$ According to our results (Table 2) several other preparations were also effective against specific groups of microorganisms when used un-diluted for longer durations. For instance, $C$. fenestratum, $A$. indica, and $C$. fistula decoctions showed inhibition zones against both $S$ aureus and $S$ pyogenes. Inhibition zones $>10 \mathrm{~mm}$ indicate strong antimicrobial activity ${ }^{19}$.

The activity of medicinal plant extracts has been intensely studied during recent times. However, varying results have also been observed in different studies. For instance, our results showed that E. officinalis extract is not effective against Candida albicans, which contradicts finding of several other researchers. ${ }^{17,18}$ The effectiveness of the preparation might be influenced by the extraction method. Antimicrobial activity of medicinal plants has been demonstrated to be higher in organic extracts than aqueous extracts ${ }^{20,21}$.

Increasing failure of chemotherapeutic antimicrobial agents has been reported due to development of antimicrobial resistance. ${ }^{3-6}$ Since herbal plants contain natural antimicrobial substances such as alkaloids, flavones (flavonoids, flavonols, quinones), essential oils, lectins, polypeptides, phenolics, polyphenols, tannins and terpenoids, ${ }^{8}$ they have very minimal side effects when compared with chemotherapeutic antimicrobial agents 22 .

In conclusion, Ayurvedic preparations show promising antimicrobial activity against microorganisms causing superficial skin infections. We suggest the use of decoctions prepared from $T$. chebula, T. belerica, E. officinalis mixture and T. chebula as a universal treatment against microorganisms causing superficial skin infections including $T$ rubrum, $M$ gypsum, $C$ albicans, $M$ furfur, $S$ aureus and $S$ pyogenes.

\section{References}

1. Resnick S. Staphylococcal and streptococcal skin infections: pyodermas and toxin-mediated syndromes. In: Harper JO A, Prose N, eds. Textbook of pediatric dermatology. Oxford: Blackwell, pp. 369-77, 2000.

2. Aly R. Skin, hair and nail fungal infections. Curr Opin Infect Dis 1998; 11(2): 113-8. http://dx.doi.org/10.1097/00001432-199804000-00004 
3. Goh CL, Tay YK, Ali KB, Koh MT, Seow CS. In vitro evaluation of griseofulvin, ketoconazole, and itraconazole against various dermatophytes in Singapore. Int J Dermatol 1994; 33(10):733-7. http://dx.doi.org/10.1111/j.1365-4362.1994.tb01523.x

4. Isham N, Ghannoum MA. In vitro evaluation of voriconazole demonstrates potent antifungal activity against dermatophytes. 41st Interscience Conference on Antimicrobial Agents and Chemotherapy (ICAAC), 2001; Abstract J-815: 380. No doi

5. Stoddart B, Collyns T, Denton M. Fusidic acid cream for impetigo. Problem may be clinically important. BMJ 2002; 324(7350):1394.

http://dx.doi.org/10.1136/bmj.324.7350.1394/a

6. Weston VC, Boswell TC, Finch RG, Perkins W. Fusidic acid cream for impetigo. Emergence of resistance to fusidic acid limits its use. BMJ 2002; 324(7350):

1394. http://dx.doi.org/10.1136/bmj.324.7350.1394/a

7. Jain SK. Ethnobotany and research on medicinal plants in India. Ciba Found Symp 1994; 185:153-64; discussion 164-8. No doi

8. Samy RP, Gopalakrishnakone P. Therapeutic potentials of plants as antimicrobials for drug discovery. Evidence-Based Complementary and Alternative Medicine 2010; 7(3):283-294. http://dx.doi.org/10.1093/ecam/nen036

9. Lorenzini R, Mercantini R, and De Bernardis F. In vitro sensitivity of Malassezia spp. to various antimycotics. Drugs Exp Clin Res, 1985; 11(6):393-5. No doi

10. Magaldi $\mathrm{S}$ et al. Well diffusion for antifungal susceptibility testing. Int $J$ Infect Dis, 2004; 8(1):39-45. http://dx.doi.org/10.1016/j.ijid.2003.03.002

11. Yamada Y and Azuma K. Evaluation of the in vitro antifungal activity of Allicin. Antimicrob Agents Chemother. 1977 ; 11(4):743-749. http://dx.doi.org/10.1128/AAC.11.4.743

12. Bansod S and Rai M. Antifungal activity of essential oils from Indian medicinal plants against human pathogenic Aspergillus fumigates and A. niger. World J. Medical Sci.2008; 3(2):81-88 No doi

13. Bag A, Bhattacharyya SK, Bharati P, Pal NK, Chattopadhyay RR. Evaluation of antibacterial properties of Chebulic myrobalan (fruit of Terminalia chebula Retz.) extracts against methicillin resistant Staphylococcus aureus and trimethoprimsulphamethoxazole resistant uropathogenic Escherichia coli. African Journal of Plant Science 2009; 3(2):25-9. No doi

14. Chattopadhyay RR, Bhattacharyya SK, Medda C, Chanda S, Datta S, Pal NK. Antibacterial activity of black myrobalan (Fruit of Terminalia chebula Retz.) against uropathogen Escherichia coli Phcog Rev. 2007; 11:212-5. No doi 
15. Kim HG, Cho JH, Jeong EY, Lim JH, Lee SH, Lee HS. Growth-inhibiting activity of active component isolated from Terminalia chebula fruits against intestinal bacteria. J Food Prot 2006; 69(9):2205-9. No doi

16. Malekzadeh F, Ehsanifar H, Shahamat M, Levin M, Colwell RR. Antibacterial activity of black myrobalan (Terminalia chebula Retz) against Helicobacter pylori. Int J Antimicrob Agents 2001; 18(1):85-8. No doi

17. Aqil F, Khan MS, Owais M, Ahmad I. Effect of certain bioactive plant extracts on clinical isolates of beta-lactamase producing methicillin resistant Staphylococcus aureus. J Basic Microbiol 2005; 45(2):106-14.

http://dx.doi.org/10.1002/jobm.200410355

18. Sahabat S, Tariq P. Antimicrobial activities of Emblica officinalis and Coriandrum sativum gram positive bacteria and Candida albicans. Pak. J. Bot 2007; 39(3):913-7. No doi

19. Rani P, Khullar N. Antimicrobial evaluation of some medicinal plants for their anti-enteric potential against multi-drug resistant Salmonella typhi. Phytother Res 2004; 18(8):670-3. http://dx.doi.org/10.1002/ptr.1522

20. Khanna PGA, Chauhan A, Chauhan G, Kaushik P. In vitro evaluation of crude extracts of Catharanthus roseus for potential antibacterial activity. Int J Green Pharm 2008; 2(3):176-181. http://dx.doi.org/10.4103/0973-8258.42739

21. Srikrishna LP, Vagdevi HM, Basavaraja BM, Vaidya VP. Evaluations of antimicrobial and analgesic activities of Aporosa lindleyana (euphorbiaceae) bark extract. Int J Green Pharm 2008; 2(3):155-7. http://dx.doi.org/10.4103/09738258.42733

22. Popat A, Shear NH, Malkiewicz I, Stewart MJ, Steenkamp V, Thomson S, et al. The toxicity of Callilepis laureola, a South African traditional herbal medicine. Clin Biochem 2001; 34(3):229-36. http://dx.doi.org/10.1016/S0009-9120(01)00219-3 